\title{
Genetiske faktorer og bivirkninger hos barn med akutt lymfatisk leukemi
}

\author{
Genprofilering kan være en mulighet for å identifisere pasienter med høy \\ risiko for alvorlige infeksjoner.
}

Overlevelsen for barn med akutt lymfatisk leukemi er på rundt $85 \%$. Hos dem som dør, skyldes $75 \%$ av dødsfallene kreftsykdommen i seg selv, de resterende $25 \%$ skyldes bivirkninger av behandlingen.

Vi undersøkte risikofaktorer og dødsårsaker i 88 tilfeller av bivirkningsrelatert dødsfall blant 2700 pasienter med akutt lymfatisk leukemi i Sverige, Danmark, Finland, Island og Norge i perioden 1992-2008. Vi undersøkte også om mønstre av enkeltnukleotidpolymorfismer kunne spille en rolle for risikoen for alvorlige infeksjoner under leukemibehandlingen.

Forekomsten av bivirkningsrelatert dødsfall var 3,2\%, og vi fant at risikofaktorene var kjønn (pike), behandlingsintensitet (høyrisikopasienter), T-cellesykdom, Downs syndrom og gjennomgått beinmargstransplantasjon. Av dødsårsaker var det 75\% infeksjoner, $10 \%$ blødninger, $10 \%$ spesifikk organsvikt og $5 \%$ direkte kreftcellepåvirkning (tumorbyrde).
Blant 34000 enkeltnukleotidpolymorfismer relatert til akutt lymfatisk leukemi hos barn identifiserte vi 24 som var assosiert med risiko for infeksjon. Ut fra fire enkeltnukleotidpolymorfismer, koblet sammen i en enkeltnukleotidpolymorfismeprofil, var vi i stand til å forutsi risikoen for infeksjoner de første 50 dagene av behandlingen med stor nøyaktighet. Enkeltnukleotidpolymorfismene tilhører genene OR51F1, CBR1, POLDIP3 og $C C L 11$, som bl.a. regulerer cellegiftomsetning, cellevekst og betennelsesreaksjoner. Hvis disse funnene blir bekreftet i større studier, vil denne kunnskapen kunne brukes til bedre å skreddersy behandlingen til enkeltpasienter og dermed redusere forekomsten av alvorlige bivirkninger.

\section{Bendik Lund}

bendik.lund@ntnu.no

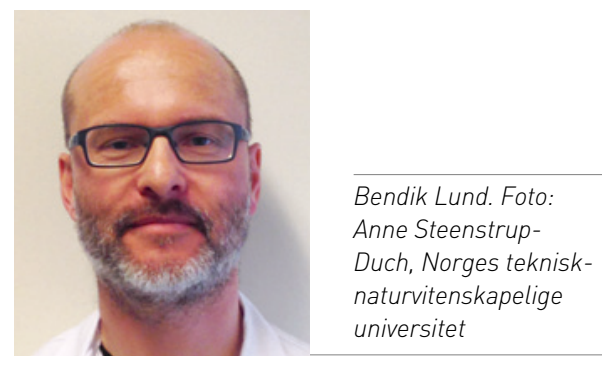

Disputas

Bendik Lund disputerte for ph.d.-graden ved Norges teknisk-naturvitenskapelige universitet 14.2. 2014. Tittelen på avhandlingen er Host genome variation and toxicity in childhood acute lymphoblastic leukaemia.

\section{Nye materialer i hofteproteser}

\section{Nye materialer i hofteproteser innebærer en forandring, men ikke alltid en forbedring.}

Hvert år behandles ca. 8000 mennesker i Norge med totalprotese $\mathrm{i}$ hofteleddet, og generelt er resultatene gode. Som ledd i forbedringen av holdbarhet og funksjon utvikles det stadig proteser i nye materialer og ny design. Disse er imidlertid ikke underlagt samme regulering som blant annet legemidler. Denne randomiserte kliniske studien ble utført som ledd i en gradvis introduksjon av nye proteser.

Oksinium er et forholdsvis nytt materiale i leddhoder. Vi fant at bruken av dette ikke reduserte slitasjen sammenliknet med vanlige kobolt-krom-hoder etter to års oppfølging, uansett materiale i plastkoppen. Vi fant dessuten at sterkt kryssbundne plastkopper hadde vesentlig mindre slitasje enn ikke-kryssbundne kopper.

Videre påviste vi at Spectron EF Primaryprotesestammen var mer stabil enn Charnley- protesen etter to år. Økt stabilitet er teoretisk forenlig med bedre langtidsresultater, men registerdata viser bedre proteseoverlevelse for Charnley-protesen. Initial stabilitet betyr derfor ikke alltid bedre overlevelse, noe som mest sannsynlig kan forklares av forskjell i overflate og design. Vi kunne ikke påvise at helningsvinkelen på koppen påvirket slitasjen, noe som tidligere har vært en vanlig antakelse.

Funnene tilsier at det ennå ikke er påvist fordeler ved å bruke oksiniumleddhoder. Sterkt kryssbunden plast bør brukes som koppmateriale. Våre funn understreker betydningen av gradvis introduksjon av nye hofteproteser og at alle proteser følges opp i Nasjonalt register for leddproteser.

\section{Thomas Kadar}

thomas.istvan.edelsvard.kadar@helse-bergen.no

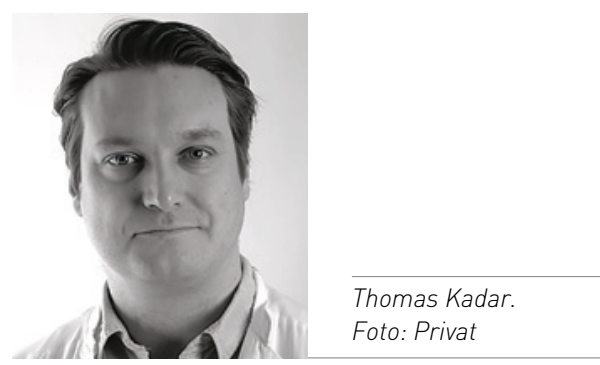

Disputas

Thomas Kadar disputerte for ph.d.-graden ved Universitetet i Bergen 6.3. 2014. Tittelen på avhandlingen er Wear and migration in cemented total hip arthroplasty. 